\title{
Special Issue Introduction: Creativity and Creative Work in Contemporary Working Contexts
}

\author{
Karen Littleton • Stephanie Taylor • \\ Anneli Eteläpelto
}

Received: 17 August 2011 /Accepted: 18 August 2011 /

Published online: 2 September 2011

(C) Springer Science+Business Media B.V. 2011

Creativity within working contexts, including organisations and professional domains, is an object of inquiry for educators, managers and researchers. Their concerns vary and give rise to different questions, as a closer examination of different cases reveals. What, for instance, is understood to be the site and nature of creativity? What exactly is meant by 'creative work' or a 'creative career'? What is assumed to operate as a constraint or obstacle to creative processes and creative working and, conversely, how are they seen to be nurtured? Such questions do not admit of easy answers because creativity in contemporary work contexts is a multifaceted phenomenon. As the articles in this special issue show, any attempt to investigate it must contend with the multiple definitions and associations of the creative. This can variously encompass or be opposed to the 'scientific', 'technical' or 'professional'. It can be associated with the limited and specific domains of the artist, designer or musician or, alternatively, interpreted as present within all areas of working life. In this latter meaning, creativity becomes a necessary tool for survival for contemporary workers, enabling them to be flexible and entrepreneurial, inside and outside organisations, to re-shape their work identities, negotiate uncertain career pathways and generally manage unpredictable situations, including the precarious circumstances of the knowledge economy. In this special issue, an example of this 'instrumental' characterisation of creativity appears in the article by Susanna Paloniemi and Kaija Collin in which they discuss the collective and inter-

K. Littleton $(\bowtie)$

Centre for Research in Education \& Educational Technology, The Open University, Walton Hall, Milton Keynes MK7 6AA, UK

e-mail: k.s.littleton@open.ac.uk

S. Taylor

Psychology Social Sciences, The Open University, Walton Hall, Milton Keynes,

Bucks MK7 6AA, UK

A. Eteläpelto

Department of Educational Sciences, University of Jyväskylä, PO Box 35, 40014, Jyväskylä, Finland 
professional creativity required to solve the practical problems which arise in the context of a surgical clinic.

One common attraction of the concept of the creative is its association with the new, so that creativity becomes linked to innovation, whether of products, life possibilities or solutions to problems. If creativity is associated with innovation and newness, then it acquires a special relevance for workers at transition points in their careers, including those associated with the move into working life, changes within work organisations and short-term or precarious employment. Two articles in the issue accordingly focus on the negotiations which are part of the ongoing construction of contemporary career trajectories and the taking up of new identities. Sini Juuti and Karen Littleton consider the transition from formal study to a career in classical music, and Stephanie Taylor discusses conflicts faced by creative workers for whom a career entry point is 'art college' Higher Education study in Art and Design.

The study of creativity has conventionally centred on a creative individual, such as the minimally defined universal figure of conventional psychological models of creativity (e.g. Amabile 1983) or the image of a celebrated named individual within the creative and performing arts. This focus has been challenged by psychologists, such as Keith Sawyer, Dorothy Miell and Karen Littleton (see for example Miell and Littleton 2004; Eteläpelto and Lahti 2008), who have explored the collaborative nature of creativity. Their work has emphasised connections, between people and often across time, investigating creative relationships (John-Steiner 2000), the interactions and shared practices which contribute to group creativity (Sawyer 2004) and the larger social contexts within which creative processes and outputs come to be recognised and given value.

Sociological theorists have also challenged the conventional reference of the creative in terms of an individual, such as the mythical artist figure. Their interest is in the potential congruence between the image of a creative individual and the agentic entrepreneur who has been celebrated as an ideal contemporary worker. The double image is linked by some theorists to the rise of the neo-liberal subject as a form of person-making, a contemporary way of viewing and doing the self (Rose 1996). Sociologists have also noted the expanded reference of creativity to take in a broad range of activities and occupations within the so-called creative industries and cultural sector (McRobbie 2002), the focus of the article in this issue by Stephanie Taylor. The expansion parallels the increased rhetorical focus on creativity and innovation, leading to their prioritisation within workplaces and professions which might previously not have been discussed in these terms. The first article in the issue, by Susanna Paloniemi and Kaija Collin, again exemplifies this.

Creativity may have acquired a special status in recent times because of the uncertainty and precariousness of contemporary working lives: there is an argument that if change is inevitable, then workers must be creative in order to manage it. But this depiction may itself be partly mythical and open to contest. For example, Linda McDowell (2009) has suggested that accounts of the 'new' or knowledge economy overstate change and make insufficient acknowledgement of continuity. She argues that mobility is exaggerated and that many supposedly 'new' jobs centre on conventionally unpaid feminised tasks which have been transferred into the labour 
market from domestic contexts. Angela McRobbie (1998) has also argued that there is continuity in the older patterns of marginalisation which persist in the so-called creative industries and cultural sector: for example, women and Ethnic Minority workers are less likely to be employed in 'new' creative jobs. Such continuities can be understood in terms of work and organisational contexts which are complexly hierarchical and fractured by uneven power relationships and resistances. In contrast, collaborative creative processes can appear as an ideal or near-ideal, although one which creative workers might claim can in some instances come close to at least partial realisation.

This issue takes as a starting point socio-cultural theories of creativity as collaborative, considered in less idealised terms. Researchers in this tradition have suggested that creativity always takes place in a community linked by common identities and a feeling of belonging, and all the shared practices which enable communication. It is through such practices that the creative is not only enabled but categorised and valued. Although this inevitably positive valuing persists across the different meanings of creative work explored within this issue and elsewhere, the particular contribution of the special issue is to problematise the nature of collaboration, introducing greater complexity and an element of difficulty or limitation.

Writers in the socio-cultural tradition have tended to link creative collaborations with circumstances of freedom and an absence of constraint. Creativity is supposedly promoted by the untrammelled, even playful interaction of equals. This assumption is well-illustrated in the influential work of Keith Sawyer which takes improvisational theatre as both a case study and a model for the theorisation of collaborative creative processes (Sawyer 2004). The contribution of this work is widely recognised. However, in contrast to its now well-established egalitarian focus, the articles in this special issue introduce new issues by considering the constraints and conflicts around creativity and also by re-emphasising the role within collaborations of individual agency. In his own article in the special issue, Keith Sawyer returns to the study of improvisational interactions between actors in order to develop an elaborated model of collaborative creativity which incorporates the contribution of individuals as a discrete level of activity. Paloniemi and Collin similarly note that the 'practical creativity' which they investigate involves 'finding, experimenting with and transgressing the boundaries of participatory agency'. They employ the concept of discursive power to analyse the constraints on creative problem-solving within the hierarchical and status-marked workplace of the Operating Theatre. The other two articles consider the constraints on participants' discursive work to construct and claim creative identities. The effect of the Romantic myth of the artist as a powerful and sometimes inhibiting resource for sense-making is explored by Sini Juuti and Karen Littleton through their consideration of professional pianists. They look at how the identities these musicians can claim and construct (as they negotiate the transition into working life) must accommodate the traditional resources around creativity which are given by the music academy, noting the 'dilemmas in weaving together established and personal meanings'.

Taken together, the collection of articles in this special issue therefore contribute a fuller understanding of the complexity of creativity in contemporary work and its contexts through a problematisation of the social and collaborative processes recognised by socio-cultural theorists. 


\section{References}

Amabile, T. (1983). The social psychology of creativity: a componential conceptualization. Journal of Personality and Social Psychology, 45(2), 357-376.

Eteläpelto, A., \& Lahti, J. (2008). The resources and obstacles of creative collaboration in a long-term learning community. Thinking Skills and Creativity, 3(3), 226-240.

John-Steiner, V. (2000). Creative collaboration. New York: Oxford University Press.

McDowell, L. (2009). Back to the future: Change and continuity in the new economy. 6th Work Research Conference in Tampere, Tampere, November.

McRobbie, A. (1998). British fashion design: Rag trade or image industry? London and New York: Routledge.

McRobbie, A. (2002). From Holloway to Hollywood: happiness at work in the new cultural economy? In P. du Gay \& M. Pryke (Eds.), Cultural economy. London: Sage.

Miell, D., \& Littleton, K. (Eds.). (2004). Collaborative creativity: Contemporary perspectives. London: Free Association Books.

Rose, N. (1996). Inventing our selves: Psychology, power and personhood. Cambridge: Cambridge University Press.

Sawyer, R. K. (2004). Group creativity: Music, theatre, collaboration. Mahwah: Lawrence Erlbaum Associates.

Karen Littleton is Professor of Psychology in Education within the Centre for Research in Education and Educational Technology at the Open University, UK.

Stephanie Taylor is a Senior Lecturer in Psychology within the Faculty of Social Sciences at the Open University, UK.

Anneli Eteläpelto is Professor of Adult Education at the University of Jyväskylä, Finland. 